\title{
Students' Perception of the Use of Technology in Education
}

\author{
Nur Zaimah Ubaidillah, Nur Nadhira Baharuddin, Nurizwani Kasil, Farhana Ismail
}

Universiti Malaysia Sarawak, Sarawak, Malaysia

unzaimah@unimas.my¹,bnnadhira@unimas.my²,62160@siswa.unimas.my³, ifarhana@unimas.my4

Tel: $+6082-5844211$

\begin{abstract}
The changes that happen in technology recently have brought about significant changes in the field of education where it can improve the quality of knowledge with the invention of technology is creative, unique, and of course, it is beneficial to us especially among students. There is a growing number of interests in how these technological platforms are perceived by the users (students) and the effectiveness of these platforms. For this reason, it is essential to investigate the easiness and usefulness of such technology being currently used by students. To further understand the issue, the role of students' perception plays an essential role in the use of technology in education. Therefore, this study focuses on the students' understanding of the use of technology in learning among students at the University Malaysia Sarawak (UNIMAS) by applying the Technology Acceptance Model (TAM). Besides, this is an exploratory study on the impact of TAM on students' perception. An online questionnaire has been distributed, and a total of 113 respondents were collected, which aims to gather insight on the use of technology in the learning system at UNIMAS. Moreover, this study has used various analysis methods such as descriptive analysis, reliability test, factor analysis, and Pearson correlation coefficient and Partial Least SquareStructural Equation Model (PLS-SEM) to investigate the role of perceived ease of use and perceived usefulness in determining the usage of technology in the higher learning institution. The findings in this study revealed that there is a positive relationship from perceived ease of use towards the use of technology among students. The outcome of the study identifies that there is a satisfactory level of technology usage among the respondents. The results also suggest that policymakers should ensure the innovation of technology to consider the ease of use and usefulness of technology (via training and providing mobile-friendly applications) to assist students' learning in the higher learning institution. The limitations of this study are that the sample is collected at the undergraduate level. It is recommended for future research to include respondents from postgraduate levels to see any difference in their perception of technology.
\end{abstract}

Keywords: Technology acceptance model; perception of technology

eISSN: 2398-4287@ 2020. The Authors. Published for AMER ABRA cE-Bs by e-International Publishing House, Ltd., UK. This is an open access article under the CC BYNC-ND license (http://creativecommons.org/licenses/by-nc-nd/4.0/). Peer-review under responsibility of AMER (Association of Malaysian Environment-Behaviour Researchers), ABRA (Association of Behavioural Researchers on Asians) and cE-Bs (Centre for Environment-Behaviour Studies), Faculty of Architecture, Planning \& Surveying, Universiti Teknologi MARA, Malaysia.

DOI: https://doi.org/10.21834/ebpj.v5i15.2374.

\subsection{Introduction}

The progression in technology has grown exponentially and more rapidly, along with the development of human life. Technology plays an important role directly or indirectly to humans' life, especially in assisting or easing daily life and activities. The high level of information network developed thru the progression of technology managed to encourage the advancement of teaching and learning techniques to use in the traditional education system. Aside from enabling the smooth transfer of knowledge, technology advancement also enriches the learning environment by making it more effective. Gorra \& Bhati (2016) believe that the usage of laptops and mobile phones as part of the teaching and learning resources will assist the education process yet at the same time create a damaging effect to the academic environment. At the same time, Omar, Abdul Razak \& Abdul Latif (2016) argue that the technological advancement will support the

eISSN: 2398-42870 2020. The Authors. Published for AMER ABRA cE-Bs by e-International Publishing House, Ltd., UK. This is an open access article under the CC BYNC-ND license (http://creativecommons.org/licenses/by-nc-nd/4.0). Peer-review under responsibility of AMER (Association of Malaysian Environment-Behaviour Researchers), ABRA (Association of Behavioural Researchers on Asians) and cE-Bs (Centre for Environment-Behaviour Studies), Faculty of Architecture, Planning \& Surveying, Universiti Teknologi MARA, Malaysia.

DOI: https://doi.org/10.21834/ebpj.v5i15.2374. 
process of finding information, especially in the field or topic that the students interested in even without the guidance from their instructors.

Malaysia is currently shifting the educational structure by introducing the e-learning as part of the teaching and learning experience of the country. The country is gearing up in providing a high-quality education system thru the incorporation of technology in supporting students' problem-solving skills, critical thinking and completing their assignment. As a developing country, Malaysia is showing a significant improvement in technological accessibility, especially in the tertiary level, where universities were encouraged to integrate elearning system in the teaching and learning process. Universities in Malaysia is accelerating the effort in revamping the education system in line with global technological advancement. With the main objective of education inclusiveness, the understanding of students' perception on the use of technology as part of their educational experience is very important.

The use of technology in the classroom setting has been one of the focus of many studies of this century. The understanding of the impact of usage of technology in the classroom usually stems from the discussion of on the perceptions of students in deciding the adoption of technology in their learning process. Kim (2000) stated that most people refer to the modern age as the 'technology community' because of the vital and critical role plays by technology in today's society, especially among students. A study by Braham (1977) as cited in Luppicini (2005) defines technology as a set of activities designed to assist people in participating in any environment. Therefore, the study of students' perceptions on the usage of technology in education is viewed as important due to the changes in technology from time to time will eventually influence students' learning experience whether positive or negative. Understanding of students' perceptions on the use of technology in education can encourage many parties to provide effective facilities or systems that students can use in the learning process. is it that systems that use a technology provided by schools or institutions help make learning more effective? Do students use technology fully and in a good way? Furthermore, why is the reputation of some students being ruined as a result of the rapidly expanding technology nationwide? Therefore, this study aims to address students' perceptions of technology so that this study can generate relevant information to understand better the issues involved. To achieve the aims, the objective of the study specifically is to investigate the determinant of behavioural intention of using eLeaps learning platform in Universiti Malaysia Sarawak (UNIMAS).

\subsection{Literature Review}

Technology is a very important part of human life in the 21st century. The development of technology has a huge impact on a nation, group, and individual where every technology has its advantages and disadvantages. Technology is rapidly spreading like a virus spreading with immense impact, but is it possible for individuals of all ages to accept the changes that occur in today's technology age and whether we are ever ready to accept and respond to these technological advances. The development of technology has a huge impact on today's young people like the students who have to deal with today's very advanced technology. Therefore, this study seeks to look at how students' perceptions of technology use in education and how the theory of Technology Acceptance Model (TAM) play a role in studying the relationships in this study. This study focused on UNIMAS students and their responses and perceptions of using a tool or platform of technology, which is eLEAPS. eLeaps is an online based teaching and learning platform used among UNIMAS students.

\subsection{Technology Acceptance Model (TAM)}

TAM is one of the most popular theories that is used widely to explain information system usage and it associated with the name of Davis (1985). In general, Weng, Yang, Ho, \& Su (2018) said that based on the original model of TAM is the user has a direct influence on the usage of a new information system and the target of which is to measure the acceptance on the part of the system user itself. The attitudes toward using are determined by another two variables, which is perceived usefulness, PU and perceived ease of use, PEOU. Afari-Kumah \& Achampong (2010) conducted a study to investigate the effect among variables such as PEOU, PU, attitude, and $\mathrm{BI}$ toward computer usage. They concluded that the variables of PEOU, PU, attitude, computer self-efficacy, actual use, subjective norms, sociability, social presence has a positive effect of the using WebCT in the education. It benefits students, especially in enhancing their learning performance by using the tool of technology. The structure of the original TAM is as in Figure 1.

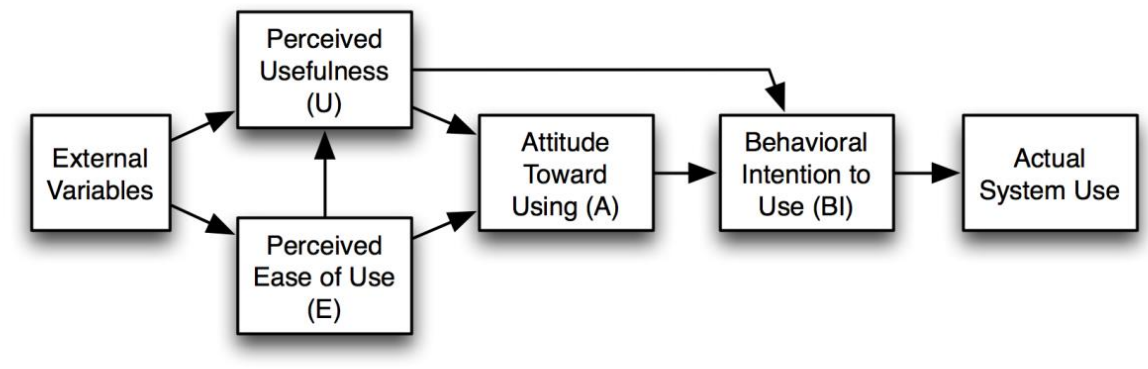

Fig. 1: Technology Acceptance Model By Davis (1986) 
Perceived ease to use is one of the independent variable (IV) in this study which to check whether this IV influences the student perception on the use of technology in the education stage. According to Weng et al. (2018), these independent variables show a positive impact on students' perceptions of technology use in education, which is a TAM-based study of the attitude towards use intention of multimedia among school teachers. However, everyone has a different view of technology use and does everyone use technology easily? Even today; we live in an increasingly complex and challenging technology environment. Therefore, these independent variables can help this study to see students' perceptions of the use of technology in education.

Perceived usefulness (PU) is also one of the independent constructs in the Technology Acceptance Model (TAM) where TAM can be referred to the theory that states one's intent to use technology and in other words one's acceptance of technology, and the individual's use of technology-based on everyone's perception of using a particular technology that provides the benefits and ease of use. Davis \& Arbor (1989) has stated the perceived usefulness as "the degree to which a person believes that using a particular system would enhance his or her job performance" and followed by the meaning of "capable of being used advantageously". This independent variable also helps researchers to investigate the impact on students' perceptions of technology use in education.

Based on the Theory of Planned Behavior (TPB) which started as the Theory of Reasoned action in 1980 explained that behavioural intention is influenced by the likelihood that will expect the behaviour outcome and the subjective evaluation which both of risks and benefits. Besides, the behavioural achievement depends on both motivation as intention and ability as behavioural control as stated by the TPB. This means the distinguishes between the three of beliefs which are the behavioural, control, and normative. Meanwhile, the TPB also mentioned, the stronger the intention to perform the behaviour, the more likely the behaviour will be performed as this refers to the motivational factors. This type of variable will help this study to investigate the student's perception on the use of technology which tool or system of technology that provided and created by the university in educational that had been used as a platform to all citizen in UNIMAS. What thing motivates the students, lectures, and citizens use the tool without any issues.

Davis and Arbor (1989) defined the actual use of a system as the frequency as well as the volume of the system used by the user. Davis clarifies that the actual system usage influenced by behavioural intention because of the identification, internalization and probably influence directly through compliance. Nakayima (2011) argued that the actual usage should inform the user about the system such as the most relevant of the system due to a bad impact to the system. He also includes the actual use as a variable to investigate the impact and influence toward students' perception on the use of technology in education.

\subsection{Empirical Evidence}

The study of evaluation of online video usage and learning satisfaction by Nagy (2018) shows that the used of partial least square (PLS) regression as a methodology to examine for each variable are a success when the result shows that the PEOU, PU, and attitude is influencing the actual usage of the technology. The variable of learning satisfaction and interest self-efficacy of students have a positive effect on the learning performance, which means to say that the incorporation of technology in education process will eventually benefit the students' learning experience. Furthermore, both of learner-learner interaction and learner-teacher interaction have a positive effect on learning performance of students; however, learner-teacher interaction is the most influencing the learning performance. Students can be taking advantage of several interactive tools, such as instant messages, emails, forums, discussion boards, voice calls, video calls, voice, and video conferencing trials. All these interaction tools are for supportive interactions with other students and teachers, and one of these tools can be integrated into e-learning systems, such as Moodle (Nagy, 2018). Both PEOU and PU have a direct effect of student's perception of the use of technology in education.

Alharbi \& Drew (2014) has focused the study on using TAM in understanding academics' behavioural intention to use learning management systems (LMS) and conducted this study at Shaqra University, Saudi Arabia which collect the respondent through questionnaire and only 59 faculty members from different colleges and departments have participated in the online survey. This study investigates the relationship of the dependent variable (job relevance, lack of LMS availability, and LMS usage experience) with the independent variable (TAM). The study concluded that a strong relationship of job relevance with PU due to the use of LMS teaching is relevant to their courses. Also, LMS as a tool used in e-learning helps to improve learning performance as well their productivity.

A study on e-Learning acceptance based on TAM by Ibrahim et al. (2018) in one of the universities in Malaysia concluded that respondents had the experience of the using e-learning systems in their previous semester. According to the same study students' decision to use e-learning is not affected by the instructor characteristic but rather being influence by perceived usefulness and ease of use on the e-learning process used in the teaching and learning process. This is also supported by Masrom, Zainon, \& Rahiman (2008) which highlighted that e-learning is considered as one of the technology systems that can assist the transfer of knowledge from the lecturer to the students by allowing the sharing of schedule, course outline and teaching materials. The used of various of methodologies such as Cronbach' alpha, Statistical analysis system (SAS) and Separate linear regression analysis is to find the result and shows that PEOU had a positive influence on the PU. Then, both of PEOU and PU affected the attitude to use the technology in e-learning and PEOU and PU had a positive effect on the intention to use the technology.

The findings from Chung, Chen, \& Kuo (2015) study shows that compatibility, self-efficacy, PEOU, and PU have a positive relationship with the behavioural intention of the college students' acceptance on mobile learning such as outcome from the survey showed that the students' as learners agree that the user of mobile vocabulary learning application can enhance the efficiency of their learning process due to the usefulness. PEOU has a positive effect on the learner's performance because it can save time when using mobile phones. Amornkitpinyo \& Wannapiroon (2015) conducted a study to investigate the causal relationship between variables in TAM with the online learning acceptance and behavioural intention to use the innovation in the 21 st century among graduate students. This study found the causal relationship between the variables and the actual use of technology in the education system. Therefore, in order to promote e-teaching and learning, the actual usage should be beneficial to the actual users. 


\subsection{Methodology}

The approach of the students' perception study is focusing the quantitative research. The primary data collection method is used in obtaining the data of this study through the online questionnaire, where a total of 113 of respondents has been collected from students of Faculty of Economics and Business, UNIMAS from September to January 2020. The questionnaire has two sections, namely section $A$, and $B$. In section $A$ consists of demographic information of the respondents, while section $B$ contains questions related to TAM that is perceive ease of use, perceived usefulness, behavioural intention, and actual use. A response rate of approximately 80 per cent was attained, which shows a very high level of participation among the respondents. Data obtained had been analyzed using Partial Least Squares-Structural Equation Model (PLS-SEM). The method is used to seek the relationship between variables of multiple indicators in determining the dependent variables which are the behavioural intention and actual usage in this case. Furthermore, PLS-SEM is widely used for explanatory research and also studies with small sampling. PLS-SEM consists of two assessments which are the assessment of the measurement model and the assessment of the structural model.

Figure 2 shows the conceptual framework of the study.

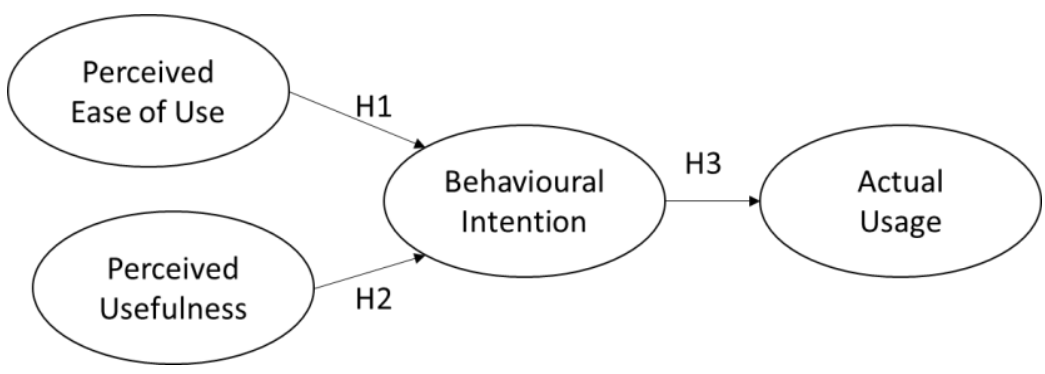

Fig. 2: Conceptual Framework Study

\subsection{Research Hypothesis}

Figure 2 shows the conceptual framework of the study by applying TAM. Hypotheses are formulated to determine the relationship independent variable (perceive ease of use and perceive usefulness) with students' behavioural intention and actual use. Four hypotheses had been formulated in this study:

H1: Perceived ease of use has a significant positive effect on behavioural intention;

H2: Perceived usefulness has a significant positive effect on behavioural intention;

H3: Behavioural Intention has a significant positive effect on actual behaviour.

In this study, perceived ease of use is expected to have a positive effect to students' perception of the use technology in education as stated by Khee, Wei, \& Jamaluddin (2014) which shows the most of students preferred YouTube as a platform to watch the lectures for ease of use due to convenience and not face difficulties in accessing lectures captures. Perceived usefulness is expected to have a positive effect to students' perception of the use technology in education as stated by Zogheib, Rabaa'i, Zogheib, \& Elsaheli (2015) which found that perceived usefulness influences the students' perception of use technology in mathematics learning.

\subsection{Findings and discussion}

Based on the PLS-SEM analysis, the outcome is presented in Table 1 based on the assessment of the measurement model and the assessment of the structural model. The assessment of the measurement model comprises of several evaluations, including indicators' reliability, convergent validity, and discriminant validity. For the indicators' reliability, the constructs are held with loadings of 0.796 to 0.841 . On the other hand, for convergent validity, the average variance extracted (AVE) is accepted with a value higher than 0.50 . Finally, for discriminant validity, the results are acceptable in which the loadings of each construct are the highest for the respective construct in Table 2.

Table 1. Measurement Model

\begin{tabular}{|c|c|c|c|c|}
\hline Construct & Items & Loadings & AVE & CR \\
\hline Perceived Ease of Use & PEU1 & 0.799 & 0.89 & 0.669 \\
\hline & PEU2 & 0.841 & & \\
\hline & PEU3 & 0.835 & & \\
\hline
\end{tabular}




\begin{tabular}{|c|c|c|c|c|}
\hline & PEU4 & 0.796 & & \\
\hline & PU1 & 0.816 & 0.903 & 0.651 \\
\hline Perceived Usefulness & PU2 & 0.825 & & \\
\hline & PU3 & 0.804 & & \\
\hline & PU4 & 0.793 & & \\
\hline & PU5 & 0.795 & & 0.677 \\
\hline Behavioural Intention & B11 & 0.837 & 0.863 & \\
\hline & Bl2 & 0.82 & & 0.852 \\
\hline Actual Use & B13 & 0.811 & & \\
\hline & AU1 & 0.911 & 0.92 & \\
\hline & AU2 & 0.935 & & \\
\hline
\end{tabular}

Table 2. Discriminant Validity using Fornell and Lacker Criterion

\begin{tabular}{|c|c|c|c|c|}
\hline & $\begin{array}{c}\text { ACTUAL } \\
\text { BEHAVIOUR }\end{array}$ & INTENTION & PEU & PU \\
\hline ACTUAL BEHAVIOUR & $\mathbf{0 . 9 2 3}$ & & & \\
\hline INTENTION & 0.579 & $\mathbf{0 . 8 2 3}$ & & \\
\hline PEU & 0.325 & 0.478 & $\mathbf{0 . 8 1 8}$ & \\
\hline PU & 0.594 & 0.658 & 0.55 & 0.807 \\
\hline
\end{tabular}

For the assessment of the structural model, the values of the coefficient of determination $\left(R^{2}\right)$ recorded are 0.452 and 0.335 , which indicate that the relationships between the dependent and independent variables are substantial. The hypothesis testing, which is presented in Table 3 indicates that $\mathrm{H} 2$ and $\mathrm{H} 3$ are found to be supported. First, there is a significant relationship between perceived usefulness and behavioural intention. This is aligned with Alharbi \& Drew (2014) and Chung et al. (2015) which also applied TAM in their study. Second, there is a significant relationship between behavioural intention with the actual usage of technology among students. The perceived ease of use however is not significant in explaining the behavioural intention of using technology. This implies that enhancement might be needed in easing the use of technology in this case, eLeaps learning platform.

Table 3. Hypothesis testing

\begin{tabular}{|c|l|l|l|l|l|l|}
\hline Hypothesis & Relationship & Std Beta & Std Error & t-value & Decision & $\mathbf{R}^{2}$ \\
\hline$H 1$ & PEU -> BI & 0.166 & 0.107 & 1.56 & Not supported & 0.452 \\
\hline$H 2$ & PU -> BI & 0.566 & 0.108 & 5.225 & Supported & \\
\hline$H 3$ & Bl -> AU & 0.579 & 0.071 & 8.144 & Supported & 0.335 \\
\hline
\end{tabular}

\subsection{Conclusion\& Recommendations}

The study identified two explanatory factors that affect students' behavioural intention and actual use of technology, specifically perceive ease of use and perceive usefulness. The study also reveals that there is a satisfactory level of technology usage among the students in Universiti Malaysia Sarawak (UNIMAS). The impact of the study is aimed to provide a high-quality education system through the incorporation of technology in supporting students' problem-solving skills, critical thinking and completing their assignment. As indicated in the results, perceived usefulness will influence students' perceptions of the use of technology in education. However, the perceived ease of use is not significant towards the intention to use technology. In this case, enhancing the easiness particularly on enabling a mobile application version of the platform might be helpful to improve the students' learning. Insights gained through this study will provide an initial overview of the university administration to take action and improve facilities or systems that students can use in the learning process. Policymakers need to ensure the innovation of technology to consider the ease of use and usefulness of technology (via training and providing mobile-friendly applications) to assist students' learning in the higher learning institution to survive in the local 
and globally competitive environment. This study, however, is limited by the fact that results are based on students' perceptions about the use of technology in the classroom and specific to an undergraduate education setting. It is recommended for future research to include respondents from postgraduate levels to see any difference in their perception of technology. Also, an investigation of how this may be done on such a large scale (such as including more public and private universities) could help the policymakers in future implementation efforts.

\section{Acknowledgement}

The authors acknowledge the financial support from the Ministry of Higher Education, Malaysia and Universiti Malaysia Sarawak (UNIMAS) with Project ID: SoTL(A)/FEP/2019(2)/036. All remaining flaws are the responsibility of the authors.

\section{References}

Afari-Kumah, E., \& Achampong, A. K. (2010). Modeling computer usage intentions of tertiary students in a developing country through the Technology Acceptance Model. International Journal of Education \& Development Using Information \& Communication Technology, 6(1), 1-15. Retrieved from http://search.ebscohost.com/login.aspx?direct=true\&db=eue\&AN=51837695\&site=ehost-live\&scope=site

Alharbi, S., \& Drew, S. (2014). Using the Technology Acceptance Model in Understanding Academics' Behavioural Intention to Use Learning Management Systems. International Journal of Advanced Computer Science and Applications, 5(1). https://doi.org/10.14569/ijacsa.2014.050120

Amornkitpinyo, T., \& Wannapiroon, P. (2015). Causal Relationship Model of the Technology Acceptance Process of Learning Innovation in the 21ST Century for Graduate Students. Procedia - Social and Behavioral Sciences, 174, 2090-2095. https://doi.org/10.1016/j.sbspro.2015.02.006

Chung, H.-H., Chen, S.-C., \& Kuo, M.-H. (2015). A Study of EFL College Students' Acceptance of Mobile Learning. Procedia - Social and Behavioral Sciences, 176, 333339. https://doi.org/10.1016/j.sbspro.2015.01.479

Davis, F. D. (1985). A technology acceptance model for empirically testing new end-user information systems: Theory and results. Management. https://doi.org/oclc/56932490

Davis, F. D., \& Arbor, A. (1989). Perceived usefulness, perceived ease of use, and user acceptance of information technology. MIS Quarterly: Management Information Systems, 13(3), 319-339. https://doi.org/10.2307/249008

Gorra, V. C., \& Bhati, S. (2016). Students' perception on Use of Technology in the class room at Higher Education Institution in Phillipines | Asian Journal of Education and e-Learning. Asian Journal of Education and E-Learning, 4(3), 92-103. Retrieved from https://ajouronline.com/index.php/AJEEL/article/view/3905

Ibrahim, R., Leng, N. S., Yusoff, R. C. M., Samy, G. N., Masrom, S., \& Rizman, Z. I. (2018). E-learning acceptance based on technology acceptance model (TAM). Journal of Fundamental and Applied Sciences, 9(4S), 871. https://doi.org/10.4314/jfas.v9i4s.50

Khee, C. M., Wei, G. W., \& Jamaluddin, S. A. (2014). Students' Perception towards Lecture Capture based on the Technology Acceptance Model. Procedia - Social and Behavioral Sciences, 123, 461-469. https://doi.org/10.1016/j.sbspro.2014.01.1445

Luppicini, R. (2005). A Systems definition of educational technology in society. Educational Technology and Society, 8(3), 103-109.

Masrom, M., Zainon, O., \& Rahiman, R. (2008). Critical Success in E-learning: An Examination of Technological and Institutional Support Factors *. International Journal of Cyber Society and Education Pages, 1(2), 131-142.

Nagy, J. T. (2018). Evaluation of online video usage and learning satisfaction: An extension of the technology acceptance model. International Review of Research in Open and Distance Learning, 19(1), 160-185. https://doi.org/10.19173/irrodl.v19i1.2886

Nakayima, J. K. (2011). Perceived Usefulness, Perceived Ease of Use, Behavioural Intention to Use and Actual System Usage in Centenary Bank. Makerere University. Retrieved from http://makir.mak.ac.ug/handle/10570/2607

Normarlianie Omar, S., Amani Abdul Razak, A., \& Abdul Latif, L. (2016). Students' Perception on the Utilization of Technology in Pragmatics Learning. No. I, 1(I), 1-8. Suk Kim, J. (2000). Students' attitudes and perceptions toward technology Recommended Citation. Retrieved from https://lib.dr.iastate.edu/rtd/13909

Weng, F., Yang, R.-J., Ho, H.-J., \& Su, H.-M. (2018). A TAM-Based Study of the Attitude towards Use Intention of Multimedia among School Teachers. Applied System Innovation, 1(3), 36. https://doi.org/10.3390/asi1030036

Zogheib, B., Rabaa'i, A., Zogheib, S., \& Elsaheli, A. (2015). University student perceptions of technology use in mathematics learning. Journal of Information Technology Education: Research, 14(2015), 417-438. https://doi.org/10.28945/2315 